FORTHCOMING IN THE JANUARY ISSUE

$$
\begin{gathered}
\text { George W. Carey } \\
\text { Publius - A Split Personality? }
\end{gathered}
$$

Jack P. Geise
Republican Ideals and Contemporary Realities

Hrach Gregorian

Assessing Congressional Involvement in Foreign

Policy: Lessons of the Post-Vietnam Period

James Nendza

Political Idealism in More's Utopia

Robert Thigpen and Lyle Downing Ideology and Truth-Seeking in Liberal Theory: The Case of Ackerman's Social Justice in the Liberal State

Walter Nicgorski

The Anti-Federalist - Collected

and Interpreted:

Review Article 


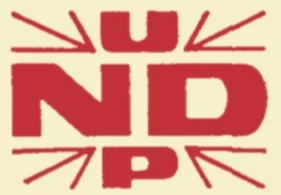

\section{University of Notre Dame Press}

